\title{
Increased cardiac contractility by decreased HAX-1 expression
}

Wen Zhao

From 2012 Sino-American Symposium on Clinical and Translational Medicine (SAS-CTM)

Shanghai, China. 27-29 June 2012

\section{Background}

The HS-1 associated protein X-1 (HAX-1) is a ubiquitously expressed protein that protects cardiomyocytes from programmed cell death. HAX-1 is mainly located in cardiac mitochondria and sarcoplasmic reticulum. Recently, it has been recognized that HAX-1 serves as a binding partner of phospholamban, which plays a fundamental role in controlling basal contractility and constitutes a key downstream effector of the $\beta$-adrenergic signaling cascade. However, the functional significance of HAX-1 in the heart remains unclear. Our previous studies have shown that overexpression of HAX-1 in vitro or in vivo by adenoviruses and transgenesis reduced cardiac myocyte contractility and calcium transients under basal condition without significant alterations of isoproterenol response. Conversely, in vitro downregulation of HAX-1 enhanced calcium kinetics and mechanics under basal conditions.

\section{Methods and results}

To further investigate the role of the endogenous HAX-1 in the cardiac contractile function, HAX-1 heterozygous deficient mice with $36 \%$ of HAX-1 expression in the heart were characterized, since the homozygous mice are lethal at 5-12 weeks afterbirth. Interestingly, in vivo echocardiography showed that decreased HAX-1 expression was associated with significantly enhanced cardiac performance, including fractional shortening and ejection frac-

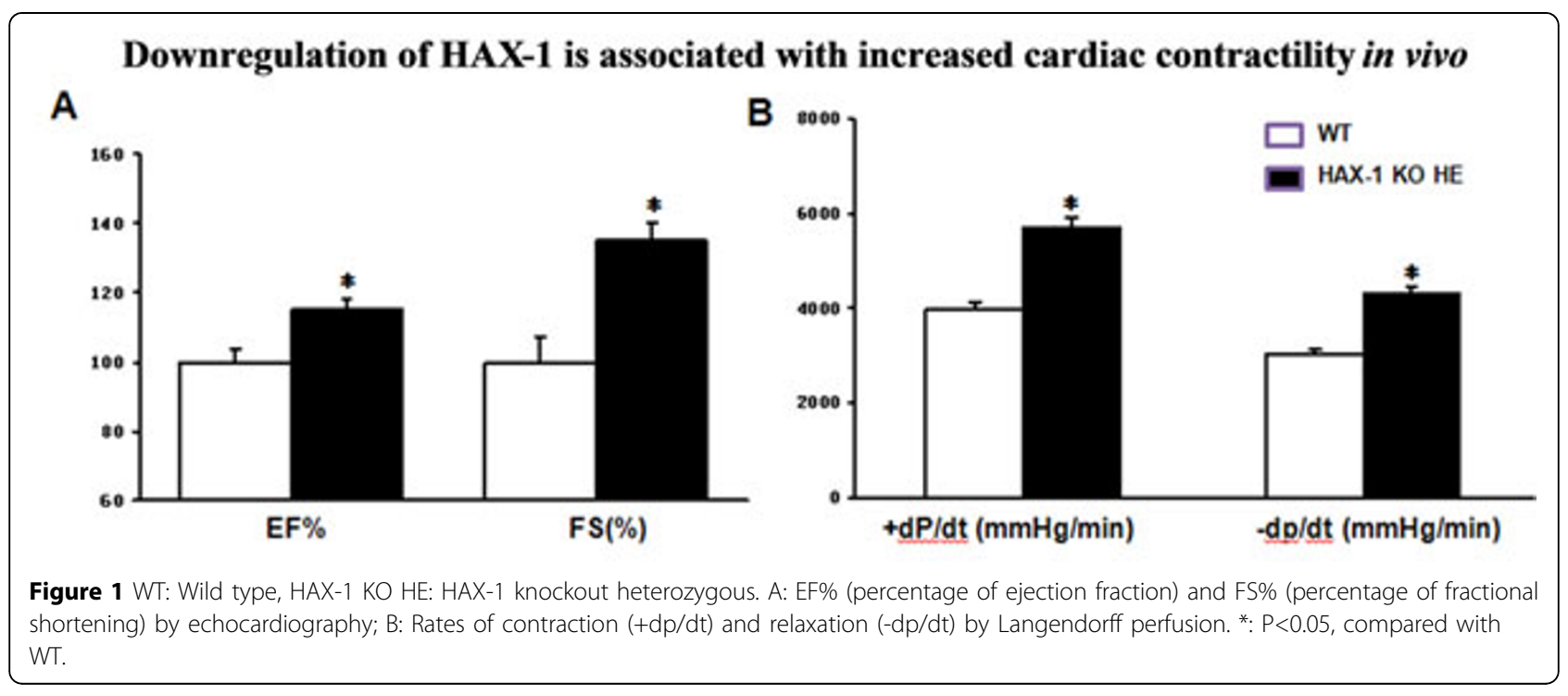

Correspondence: zhaowen100@gmail.com

School of Pharmaceutical Sciences, Zhengzhou University, 100 Kexue

Avenue, Zhengzhou, Henan 450001, China

(c) 2012 Zhao; licensee BioMed Central Ltd. This is an Open Access article distributed under the terms of the Creative Commons :HW Central Attribution License (http://creativecommons.org/licenses/by/2.0), which permits unrestricted use, distribution, and reproduction in any medium, provided the original work is properly cited. 
tion, when compared to age-matched wild types. Ex-vivo Langendorff perfusion suggested markedly increased rates of contraction and relaxation, compared to wild types (Figure 1). Furthermore, at the cardiomyocyte levels, we also found similar cardiac phenotype with elevated fractional shortening, rates of contraction and relaxation as well as calcium kinetics under basal conditions. The functional improvement in the heterozygous HAX-1 deficient mouse hearts does not plays a role in the expressions of major SR calcium handling proteins, including: SERCA2a, calsequestrin and phospholamban. However, the affinity of SERCA2 for calcium was significantly increased without alteration of maximal velocity of this calcium pump. The enhanced cardiac contractility is not related to any significant cardiac remodeling and histology changes at the age of $10-12$ weeks.

\section{Conclusion}

These results indicate that decreased HAX-1 expression in the heart is associated with increased cardiac contractility and calcium handling, suggesting that HAX-1 may be a novel regulator in cardiac contractile performance.

\section{Acknowledgement}

The author thanks Dr. Evangelia G. Kranias, who is from University of Cincinnati College of Medicine, for her constructive suggestion in the current study. This work was supported by the Starting Package of

Zhengzhou University for Wen Zhao.

Published: 17 October 2012

doi:10.1186/1479-5876-10-S2-A65

Cite this article as: Zhao: Increased cardiac contractility by decreased

HAX-1 expression. Journal of Translational Medicine 2012 10(Suppl 2):A65.

\section{Submit your next manuscript to BioMed Central} and take full advantage of:

- Convenient online submission

- Thorough peer review

- No space constraints or color figure charges

- Immediate publication on acceptance

- Inclusion in PubMed, CAS, Scopus and Google Scholar

- Research which is freely available for redistribution

Submit your manuscript at www.biomedcentral.com/submit 